\title{
Retracted: Enrichment Factors and Resource Potential Evaluation of Qingshankou Formation Lacustrine Shale Oil in the Southern Songliao Basin, NE China
}

\author{
Geofluids \\ Received 2 June 2022; Accepted 2 June 2022; Published 12 December 2022 \\ Copyright ( 2022 Geofluids. This is an open access article distributed under the Creative Commons Attribution License, which \\ permits unrestricted use, distribution, and reproduction in any medium, provided the original work is properly cited.
}

Geofluids and the authors have retracted the article. "Enrichment Factors and Resource Potential Evaluation of Qingshankou Formation Lacustrine Shale Oil in the Southern Songliao Basin, NE China" [1]. The data presented is the result of a collaboration by Jilin Oilfield, China Geological Survey and Northeast Petroleum University. The authors did not obtain permission from all data owners before publication, and therefore the article has been retracted and removed. The retraction and removal has been approved by the Chief Editor of the journal. The authors agree to the retraction and the notice.

\section{References}

[1] L. Luo, D. Tan, X. Zha et al., "Enrichment Factors and Resource Potential Evaluation of Qingshankou Formation Lacustrine Shale Oil in the Southern Songliao Basin, NE China," Geofluids, vol. 2021, Article ID 6645467, 20 pages, 2021. 


\title{
Enrichment Factors and Resource Potential Evaluation of Qingshankou Formation Lacustrine Shale Oil in the Southern Songliao Basin, NE China
}

\author{
Long Luo $\mathbb{D}^{1,2,3,4}$ Dongping Tan, ${ }^{3}$ Xiaojun Zha, ${ }^{3}$ Xianfeng Tan $\mathbb{D}^{1,2,3,4}{ }^{\text {Jing Bai, }}{ }^{1}$ \\ Cong Zhang, ${ }^{1}$ Jia Wang, ${ }^{3}$ Lei Zhang, ${ }^{3,4}$ and Xuanbo Gao ${ }^{3}$ \\ ${ }^{1}$ The Key Laboratory of Unconventional Oil \& Gas Geology, CGS, Beijing 100083, China \\ ${ }^{2}$ Shandong Provincial Key Laboratory of Depositional Mineralization \& Sedimentary Minerals, Qingdao 266590, China \\ ${ }^{3}$ College of Petroleum and Gas Engineering, Chongqing University of Science and Technology, Chongqing 401331, China \\ ${ }^{4}$ Chongqing Key Laboratory of Complex Oil and Gas Exploration and Development, Chongqing 401331, China \\ Correspondence should be addressed to Xianfeng Tan; xianfengtan8299@163.com
}

Received 5 November 2020; Revised 25 December 2020; Accepted 8 January 2021; Published 27 January 2021

Academic Editor: Kun Zhang

Copyright (c) 2021 Long Luo et al. This is an open access article distributed under the Creative Commons Attribution License, which permits unrestricted use, distribution, and reproduction in any medium, provided the original work is properly cited.

Geofluids and the authors have retracted this article. The data presented is the result of a collaboration by Jilin Oilfield, China Geological Survey and Northeast Petroleum University. The authors did not obtain permission from all data owners before publication, and therefore the article has been retracted and removed. The retraction and removal has been approved by the Chief Editor of the journal. The authors agree to the retraction and the notice. 